\title{
Multimodality imaging in a patient with hydatid disease of the pelvic bone
}

\author{
Jovis Johny, Dhilip Andrew 두 , Karthik Shyam
}

Radiology, St Johns Medical College and Hospital, Bangalore, Karnataka, India

\section{Correspondence to} Dr Karthik Shyam; dr.karthikshyam@gmail.com

Accepted 19 September 2020
Check for updates

(C) BMJ Publishing Group Limited 2020. No commercial re-use. See rights and permissions. Published by BMJ.

To cite: Johny J, Andrew D, Shyam K. BMJ Case

Rep 2020;13:e237830.

doi:10.1136/bcr-2020-

237830

\section{DESCRIPTION}

A 50-year-old man presented to the orthopaedic outpatient department with a history of fever with chills and chronic right gluteal region swelling with sudden onset increase in size following trivial trauma. On local examination, there was localised warmth with swelling and tenderness in the right gluteal region and restricted hip movements. Routine blood investigation revealed haemoglobin of $62 \mathrm{~g} / \mathrm{L}$, total leucocyte count of $15.6 \times 10^{9}$ cells/L and raised $\mathrm{C}$ reactive protein.

Anteroposterior pelvic radiograph (figure 1A) demonstrated multifocal lytic lesions of the right ilium, ischium, pubis and sacral ala. Ultrasonography of the abdomen (figure 1B) demonstrated hypoechoic collection in the right iliopsoas with near total loss of muscular architecture. MRI of pelvis (figure $2 \mathrm{~A}, \mathrm{~B}$ ) demonstrated two large communicating multiseptated T2/short tau inversion recovery hyperintense collection in the right lumbar region extending into the retroperitoneal and paraspinal region which were in communication with similar lesions in the right iliac fossa and gluteal regions. Inferiorly, there was extension into the proximal thigh with few round lesions showing internal membranes. There was near total destruction of the right hip joint and iliac bone. Plain CT of the abdomen and pelvis (figure 1C-F) demonstrated multiple subcutaneous, intramuscular, intra-abdominal and pelvic isodense to hypodense collections with the retroperitoneal and subcutaneous collections showing internal fat component and rim calcification. Based on imaging findings, possibility of hydatid disease was raised, surgical excision was performed. Histopathology of the specimen revealed features of hydatid disease.

Hydatid disease is a parasitic infection caused by Echinococcus granulosus, ${ }^{1}$ most commonly affecting the liver and lungs. ${ }^{2}$ Bone hydatid disease commonly involves vertebrae (30\% of cases) followed by pelvis $(20 \%) .^{3}$ In bone hydatid, there is no pericyst formation with the vesicles replacing the osseous tissue and causing cortical erosion with extension into the surrounding tissue. ${ }^{4-6}$ The extraosseous part of the lesion may show calcification unlike the intraosseous part which rarely shows calcification. ${ }^{5}$ The characteristic findings of bone hydatid on a radiograph are coarsened bony trabeculae with honeycomb pattern, bone expansion with cortical thinning and soft tissue swelling with calcifications. ${ }^{7}$ Typical CT findings are multiloculated osteolytic lesions with features of bone expansion, cortical thinning and adjacent soft tissue component. ${ }^{1}$ MRI can be used in assessment of the soft tissue component, which appears as multiple

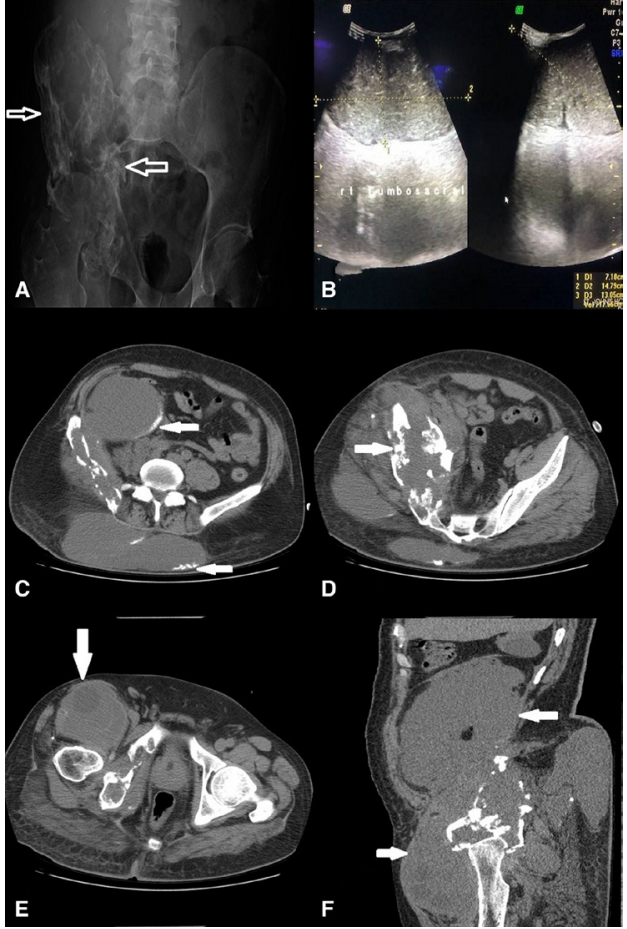

Figure 1 (A) Anteroposterior radiograph of pelvis demonstrates lytic lesions (white arrows) in the right ilium, ischium, pubis and acetabulum, (B) ultrasound image demonstrating hypoechoic collection in the right psoas region, (C, D) CT images demonstrating lytic lesions (white arrow) in the pelvic bone with intra-abdominal and subcutaneous isodense lesions with peripheral calcification (white arrow), (E, F) CT images demonstrate daughter cyst (white arrow).

vesicles showing a cyst within cyst appearance, which appears hypointense on T1 and hypo-hyperintense on T2 weighted images. The outer layer of the cyst

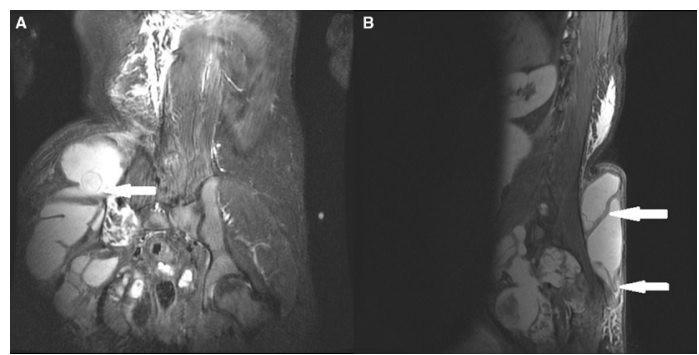

Figure 2 (A) Coronal T2 fast recovery fast spin echo (FRFSE) image demonstrates daughter cyst within the cystic lesion (white arrow) and (B) sagittal T2 FRFSE image demonstrates separated membrane from the cyst wall (serpent sign) (white arrow). 
represents pericyst which appears hypointense on T2 weighted images (rim sign), however pericysts are absent in bone hydatid. Detached membrane from cyst wall appears hypointense on all sequences (serpent sign). ${ }^{8}$

Imaging differentials include chondromyxoid fibroma, metastasis, chondrosarcoma, haemophilic pseudotumour, giant cell tumour, aneurysmal bone cyst and osteomyelitis (tuberculous). Solitary lesions can mimic simple bone cyst, plasmacytoma and brown tumour of hyperparathyroidism, while chronic hydatidosis can mimic fibrous dysplasia. ${ }^{9}$ Histopathological examination of the resected tissue is confirmatory of the diagnosis. ${ }^{10}$ Surgical excision of lesion with chemotherapy is the preferred treatment modality for bone hydatid, however advanced disease carries grave prognosis and surgery is a risky option in such cases. $^{11}$

\section{Learning points}

Key imaging of hydatid disease on radiograph and CT are lytic lesions with expansion of bone and thinning of cortex. Extraosseous component shows calcification.

- On MRI, hydatid cyst appears hyperintense with hypointense wall on T2 weighted images. Separated membrane from wall produces serpent sign.

- Key differentials for hydatid disease of bone should be kept in mind while reviewing images.

- Travel history and endemicity are important histories to be elicited.
Contributors JJ, DA and KS have drafted the article, reviewed and edited the article. All the authors have contributed equally for the article.

Funding The authors have not declared a specific grant for this research from any funding agency in the public, commercial or not-for-profit sectors.

Competing interests None declared.

Patient consent for publication Obtained.

Provenance and peer review Not commissioned; externally peer reviewed.

\section{ORCID iDs}

Dhilip Andrew http://orcid.org/0000-0002-6154-3063

Karthik Shyam http://orcid.org/0000-0003-0998-9604

\section{REFERENCES}

1 Taori K, Sanyal R, Rathod J, et al. Ct appearances of hydatid disease at various locations. Australas Radiol 2006;50:298-305.

2 Bel Hadj Youssef D, Loussaief C, Ben Rhomdhane F, et al. Kyste hydatique primitif intraosseux: à propos de deux cas. La Revue de Médecine Interne 2007;28:255-8.

3 Schneppenheim M, Jerosch J. Echinococcosis granulosus/cysticus of the tibia. Arch Orthop Trauma Surg 2003;123:107-11.

4 Torricelli P, Cristofaro RD. Radiographic and computed tomographic findings in hydatid disease of bone, 1990: 5 .

5 Oğüt AG, Kanberoğlu K, Altuğ A, et al. Ct and MRI in hydatid disease of cervical vertebrae. Neuroradiology 1992;34:430-2.

6 Braithwaite PA, Lees RF. Vertebral hydatid disease: radiological assessment. Radiology 1981;140:763-6.

7 Booz MY. The value of plain film findings in hydatid disease of bone. Clin Radiol 1993:47:265-8.

8 García-Díez Al, Ros Mendoza LH, Villacampa VM, et al. Mri evaluation of soft tissue hydatid disease. Eur Radiol 2000;10:462-6.

9 Morris BS, Madiwale CV, Garg A, et al. Hydatid disease of bone: a mimic of other skeletal pathologies. Australas Radiol 2002;46:431-4.

10 ÁA M, Herrera A, Cuenca J. Hydatidosis of the pelvis and hip;3.

11 El Ibrahimi A, Ankouz A, Daoudi A, et al. Pelvic bone and hip joint hydatid disease revealing a retroperitoneal location. Orthop Rev 2009;1:8.

Copyright 2020 BMJ Publishing Group. All rights reserved. For permission to reuse any of this content visit

https://www.bmj.com/company/products-services/rights-and-licensing/permissions/

BMJ Case Report Fellows may re-use this article for personal use and teaching without any further permission.

Become a Fellow of BMJ Case Reports today and you can:

- Submit as many cases as you like

- Enjoy fast sympathetic peer review and rapid publication of accepted articles

- Access all the published articles

Re-use any of the published material for personal use and teaching without further permission

Customer Service

If you have any further queries about your subscription, please contact our customer services team on +44 (0) 2071111105 or via email at support@bmj.com.

Visit casereports.bmj.com for more articles like this and to become a Fellow 